\title{
Analysis of the Prescriptions for Energy Quality Buildings in Three Parisian Urban Development Projects
}

\author{
Charlotte Tardieu $^{* 1}$, Morgane Colombert ${ }^{2}$, Youssef Diab ${ }^{2}$, Olivier Blanpain ${ }^{3}$ \\ ${ }^{1}$ Université Lille 1/Université Paris Est, EIVP, France \\ FranceLaboratoire TVES, UFR de Géographie et Aménagement \\ e-mail: charlotte.tardieu@eivp-paris.fr \\ ${ }^{2}$ Université Paris Est, EIVP, France \\ ${ }^{3}$ Lille 1 University, France
}

Cite as: Tardieu C., Colombert, M., Diab, Y., Blanpain O., Analysis of the Prescriptions for Energy Quality Buildings in Three Parisian Urban Development Projects, J. sustain. dev. energy water environ. syst., 3(2), pp 118-130, 2015, DOI: http://dx.doi.org/10.13044/j.sdewes.2015.03.0009

\begin{abstract}
In Paris (France), urban projects currently cover $10 \%$ of the territory. In the context of rising energy costs and the fight against climate change, reducing energy consumption in buildings and transportation is an unavoidable issue for these urban projects. While many studies analyse assessment tools and sustainability frameworks, only a few focus on developer practices. We describe how energy issues are integrated into urban development, focusing on three projects located in Paris. We compare environmental specifications made within these three projects to ensure high energy quality of the planned buildings. We observed that the way of prescribing energy performances varies from project to project. Differences in priorities from one engineering firm to another lead to a high variability of parameters identified to ensure high building energy performances.
\end{abstract}

\section{KEYWORDS}

Energy quality buildings, Urban development projects, Design prescriptions, Environmental specifications, Case studies.

\section{INTRODUCTION}

Cities are now responsible for over two-thirds of global energy consumption and more than $70 \%$ of global carbon emissions [1]. In addition, residential, tertiary buildings and transport are the main consumers of final energy in cities. For example, in London, in $2000,61 \%$ of the final energy was consumed by the residential and tertiary sectors and $28 \%$ by public transport [2]. In the current context of rising energy costs and the fight against climate change, reducing energy consumption in buildings and transportation is an unavoidable issue of urban production, and therefore development projects. In Paris (France), buildings consume about 35,000 GWh of energy every year (which represents the energy production of four nuclear power plants) and emit about 1,750,000 tonnes carbon dioxide equivalent [3]. Since the Climate Protection Plan was adopted in 2007, the primary energy consumption of new Parisian buildings is capped at $50 \mathrm{kWh}$ per square meter of net floor area per year [4].

There is much research [5-9] that provides a critical analysis of the different assessment tools and frameworks existing for sustainable buildings and urban development. However, there are fewer studies focusing on developer and designer

\footnotetext{
* Corresponding author
} 
practices outside those frameworks: "literature related to the definition, criteria and application of green specifications is relatively limited" [10]. As urban projects currently cover $10 \%$ of the Parisian territory, we decided to describe how energy issues are integrated into urban development projects from the large scale to the building scale. We have chosen to study three major Parisian operations: Paris Rive Gauche, Paris Nord Est and Clichy-Batignolles.

The purpose of this article is to identify the prescriptions set by the urban developers to the building designers in our three cases studied. We analyze what prescriptions are made concerning energy quality of buildings i.e. to enhance the energy performance of the future buildings, to optimize the renewable energy production and to reduce energy consumed during construction. We therefore compared the environmental requirements made for future buildings in our three Parisian projects.

This article is organized in three main parts. Firstly, we will briefly present the cases studied and the documents containing environmental specifications and how they were produced. Secondly, we will compare their objectives and their way of prescribing. We will then focus on their content, the parameters mentioned to ensure high energy quality buildings and the control measures proposed.

\section{COMPARISON OF ENVIRONMENTAL SPECIFICATIONS FOR BUILDINGS IN THREE CASE STUDIES}

\section{The cases studied: Paris Rive Gauche, Paris Nord Est and Clichy-Batignolles}

We focus our analysis on large urban development projects in terms of space and time. All of them are located in Paris (Figure 1), in areas characterized by railway fields or brownfields and warehouses. They are large-scale projects (from 50 hectares to more than 200 hectares), which are developed through different subdistrict operations. These are long-term projects, which began during the 1990s or the early 2000s and are still in progress. In every case, some buildings (even some sectors in Paris Rive Gauche) have already been delivered, some are still under construction, and some still need to be designed. Therefore, all of the urban projects have to achieve the ambitious objectives of the Parisian Climate Protection Plan.

Case 1: Paris Rive Gauche. One unique developer, the SEMAPA (Société d'Economie Mixte d'Aménagement de Paris) carries out the whole development project. Paris Rive Gauche is a $\mathrm{ZAC}^{\dagger}$, since a concession contract was signed between the SEMAPA and the City of Paris in 1991. The role of this semi-public company is to plan, oversee urban studies and coordinate the overall project. The area of 130 hectares is divided into nine separate sectors. Each sector is designed by one urban planner office, and so gets its own design identity.

Case 2: Paris Nord Est. In 2002, Paris Nord Est area was chosen to be part of the great urban renewal project (GPRU) of Paris. The City administration organized a design competition to select an urban planner in charge of the master plan. The 200 hectares area was divided into nine independent development sectors. These sectors follow different legal make-up, either public or private or mixed, and only start when the land is available.

\footnotetext{
${ }^{\dagger} \mathrm{A}$ ZAC is a Mixed Development Zone identified in the planning documents, where the building program is determined by a public authority. In most of the projects, a semi-public company is financially in charge of the construction through a contract with the public authority. ZAC is a French specificity very commonly used. In our study, the projects Paris Rive Gauche, Clichy-Batignolles and Claude Bernard are developed through this procedure.
} 
The overall consistency of the subdistrict operations is ensured by the urban planner and the City of Paris and not by a common developer like in the Paris Rive Gauche case.

Case 3: Clichy-Batignolles. In 2004, an urban planner was selected to draw the master plan. The division into three development operations was driven by the nature of the land and the speed at which the project could get off the ground. The Saussure sector, which had a concentration of important facilities of the French railway company (SNCF), constitutes an independent private development project supported by its own developer. The main portion was divided into two Mixed Development Zones, because the projects could not be started at the same time. Contrary to the first two cases, specific objectives for Clichy-Batignolles were fixed in the Parisian Climate Protection Plan. Indeed, it states that 'building this 'exemplary eco-district...' implies trying to balance out $\mathrm{CO}_{2}$ emissions by using renewable energy sources (solar, geothermal, biomass, etc.) and using energy-saving techniques and products wherever feasible" [4]. To achieve this goal, some requirements are listed: an energy consumption target, factors to be integrated into the architectural design, a minimum amount of renewable energy produced.

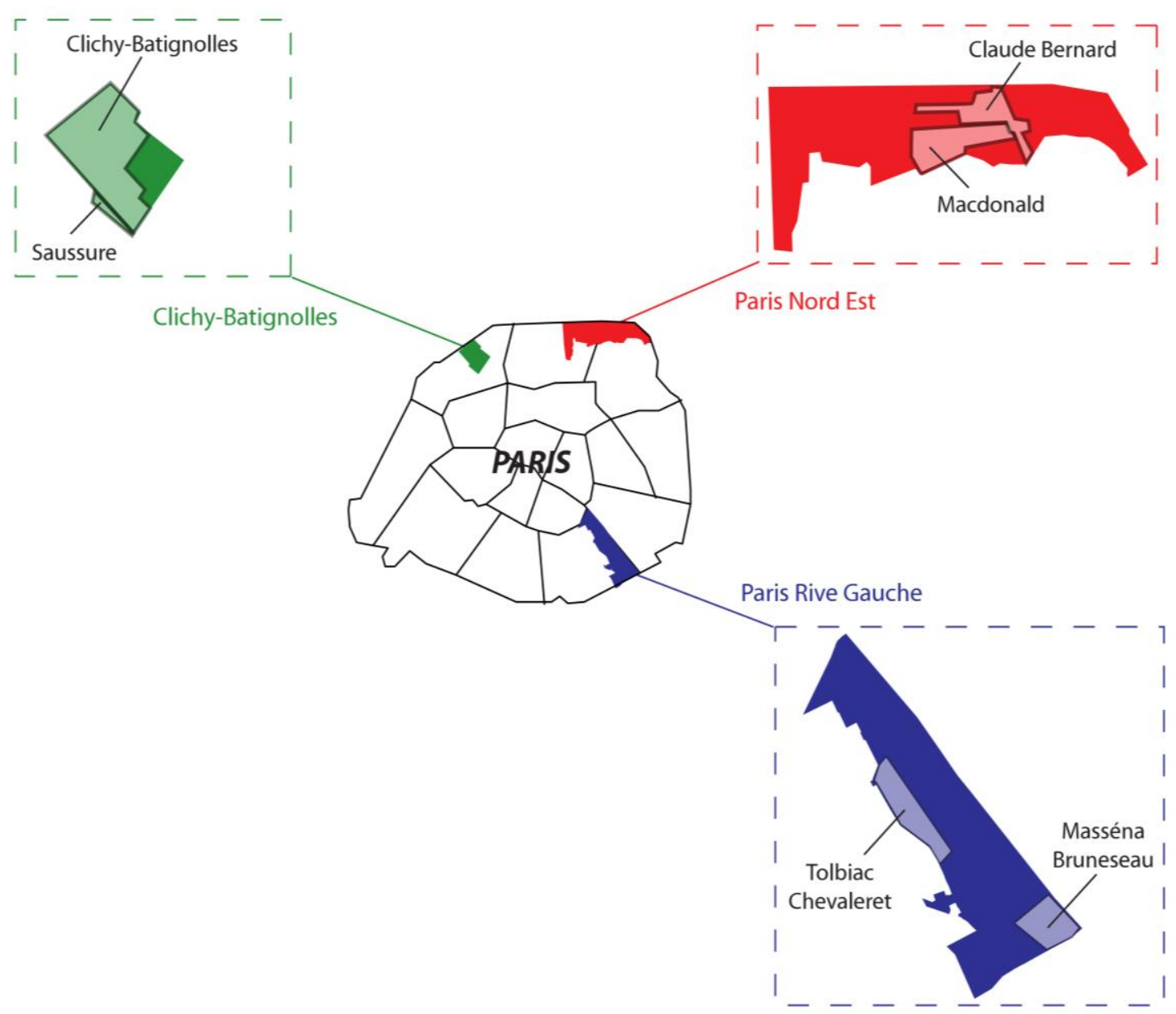

Figure 1. Localization of the development projects and subdistrict operations studied

\section{Characteristics of the environmental specifications compared: date, authors, and scale}

We have chosen to study the environmental requirements made for buildings within these projects. For this purpose, we collected documents relating to environmental 
quality for the three cases. In this article, we compare the environmental specifications of two subdistrict operations for each case study. As visible on Figure 1, these operations are:

- Tolbiac Chevaleret and Masséna-Bruneseau, subdistricts of the ZAC Paris Rive Gauche;

- Macdonald and ZAC Claude Bernard, parts of Paris Nord Est;

- Saussure and ZAC Clichy-Batignolles from Clichy-Batignolles.

Apart from the environmental specifications of ZAC Claude Bernard, all the documents we analyzed were written after 2007, after the Parisian Climate Protection Plan was adopted (Figure 2). Our comparison is enhanced by interviews with a range of project stakeholders, such as urban planners, urban developers, building developers, architects, environmental engineering firms and project managers at the City administration. These interviews have been conducted since September 2012.

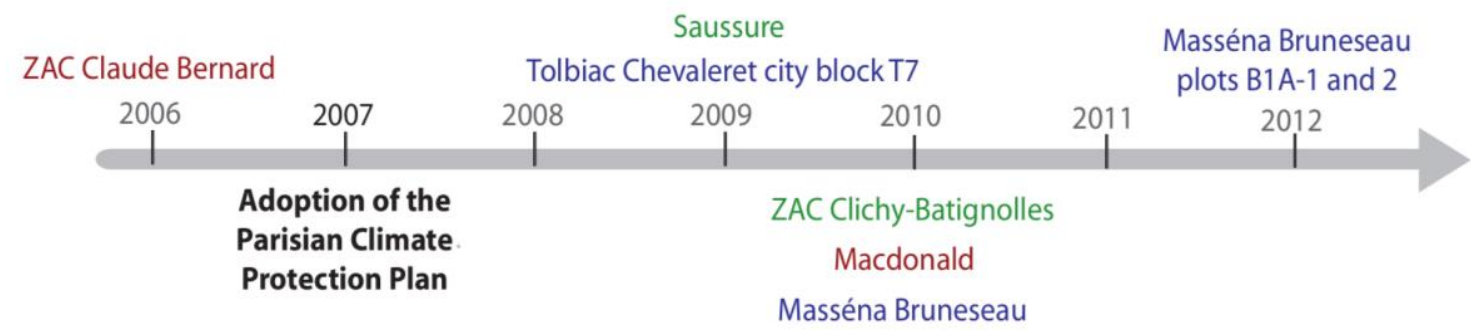

Figure 2. Chronology of the environmental specification analyzed regarding the Parisian Climate Protection Plan of Paris

Environmental requirement drafting - a widespread practice in Parisian urban development projects. In France, building energy performance is defined by the national Thermal Regulation, which only sets a goal of total primary energy consumption. Local authorities can also adopt a climate protection plan, containing consumption reduction targets for buildings. There is no legal obligation to draft environmental requirements within an urban development project, so the nature of the documents containing them is not specified by any law. However, drafting environmental specifications seems to be usual and systematic within urban development projects, in particular in our three Parisian cases. This hypothesis was confirmed by a sustainable development manager of a Parisian public authority. The specifications were written by environmental engineering firms. These firms work as Assistant to the urban Contracting Authority (ACA) with the exception of the Masséna-Bruneseau operation, where the engineering firm is part of the urban design team. In every case, these environmental prescriptions are made at the subdistrict scale. That means that the master plan of the whole development area was already drawn when they were written.

Environmental requirements in addition to sustainable development charter and environmental studies. The environmental requirements are always an implementation of the general objectives stated by a sustainable development charter. These charters are drafted by the developer team. For Paris Rive Gauche, the charter was written by the SEMAPA in 2000 for all the sectors. Environmental prescriptions in Masséna-Bruneseau and Tolbiac Chevaleret must therefore be based on this charter. In the other cases, the sustainable development charter is drafted by the Assistant to the Contracting Authority of the subdistrict operations. For every operation, studies were conducted by the environmental engineering firms. These studies can focus on energy sources for heating 
and renewable energy potential (ZAC Claude Bernard), in addition to an environmental study (Tolbiac Chevaleret) or concern all sustainable development issues (Masséna-Bruneseau, Saussure). For Macdonald operation, a thermal simulation was done in order to validate the feasibility of reaching the $50 \mathrm{kWh} / \mathrm{m}^{2}$ target. The hypotheses used in the regulatory calculation are given as guidelines only in the environmental specifications.

Environmental specifications by function, block or plot. Environmental requirements can be established for buildings at a specific location or with identified functions. Distinguished specifications for residential, office and commercial buildings are made for half of the operations studied: Macdonald, ZAC Claude Bernard and Saussure. For Tolbiac Chevaleret, environmental requirements concerning the entire sector are accompanied by detailed specifications for each block. Similarly, in Masséna Bruneseau, the environmental specifications are drafted for the whole sector [11] and specified for each plot. But in this case, the document concerning the entire sector contains a lot of recommendations on very precise aspects of the building design. Environmental specifications for every plot correspond to a contractual document describing the environmental context of the future building, its potential and all the objectives to achieve. Finally, for ZAC Clichy-Batignolles, the requirements are drafted directly for identified blocks.

In the rest of the article, we have chosen to base our comparison on the most detailed environmental requirements, i.e. the ones made for:

- Residential buildings of ZAC Claude Bernard [12], Macdonald [13] and Saussure [14];

- Block 3.4 of ZAC Clichy-Batignolles [15] and block T7 of sector Tolbiac Chevaleret [16];

- Plots B1A-1 and 2 of sector Masséna Bruneseau [17].

\section{AMBITION AND DEGREE OF CONSTRAINT}

\section{Energy consumption target, renewable energy production and energy supply}

The global energy consumption target is only detailed by energy consumption unit for Clichy-Batignolles. Buildings built in ZAC Claude Bernard must consume $20 \%$ less than the objective required by the Thermal Regulation of 2005, because the Climate Protection Plan was not yet adopted by Paris. The total primary energy consumption $\left(\mathrm{C}_{\mathrm{pe}}\right)$ target set in all the requirements drafted after 2007 is the Parisian Climate Protection Plan objective: $50 \mathrm{kWh} / \mathrm{m}^{2}$. Although, there are no calculation conventions in the Parisian climate Protection Plan, the ones used in the environmental requirements studied come from the 2005 Thermal Regulation. The energy consumption units considered in the calculation are generally mentioned and include: heating, cooling, domestic water heating, ventilation, lighting and auxiliaries. For ZAC Clichy-Batignolles only, there are precise primary energy (pe) targets for every energy consumption unit in addition to the total objective. These objectives vary depending on building functions. For example for residential buildings, the targets are:

- $\mathrm{C}_{\mathrm{pe}}$ heating $\leq 14 \mathrm{kWh}$ pe $/ \mathrm{m}^{2} \mathrm{year}$;

- $\mathrm{C}_{\mathrm{pe}} \mathrm{DWH} \leq 20 \mathrm{kWh} \mathrm{pe}_{\mathrm{p}} \mathrm{m}^{2}$ year;

- $\mathrm{C}_{\mathrm{pe}}$ specific electricity $\leq 45 \mathrm{kWh}_{\mathrm{pe}} / \mathrm{m}^{2} \mathrm{year}$;

- $\mathrm{C}_{\mathrm{pe}}$ private domestic uses $\leq 65 \mathrm{kWh}$ pe $/ \mathrm{m}^{2}$ year.
$\mathrm{C}_{\mathrm{pe}}$ : Consumption of primary energy

DWH: Domestic Hot Water 
Greenhouse gases emission objectives are stated in specifications for Macdonald and Masséna Bruneseau only. For the first one, greenhouse gas emissions need to be evaluated per square meter built and for the second one, greenhouse gas emissions are one of the chosen criteria for energy supply sources.

Environmental certifications also required. In all the specifications, apart for the ones for Saussure, residential buildings must be certified by CERQUAL, an independent French certifier, and obtain the label Habitat\&Environnement (H\&E) certification (2005 version). This certification is inspired by the Haute Qualite Environnementale (High Environmental Quality) principles. This environmental quality approach for buildings, developed by the French HQE association in 2001, is based on 14 targets with three levels of achievement: base, effective and very effective. To succeed, you must obtain 7 basic, 4 effective and 3 very effective targets. If certification is useful to building developers to commercialize the new housing and to guarantee their environmental quality, we can wonder why they are required in addition to a set of prescriptions by the urban developers. Prescriptions can be a way to ensure overall consistency of the project and respect local environmental specificities.

Paris Nord-Est and Clichy-Batignolles. renewable energy production targets and connection to the heat district demanded. Objectives in terms of renewable energy production are very clear for ZAC Claude Bernard, Macdonald and ZAC Clichy-Batignolles, expressed with a quantified target. In the first two cases, renewable production must achieve $25 \%$ of the final energy demand. For Macdonald buildings, $30 \%$ of the energy necessary for domestic water heating must be produced by solar panels. If there is no target for solar thermal energy in ZAC Clichy-Batignolles, there is a precise target for photovoltaic production: $96 \mathrm{MWh}$ per year at least must be injected into the electric grid. No specific target is requested in Saussure, but installation of solar panels on roofs is recommended.

Paris Rive Gauche: comparing of the different available energy resources. The connection to the heat network is requested whenever possible for buildings of ZAC Clichy-Batignolles and Saussure, and expressly demanded for buildings of ZAC Claude Bernard and Macdonald. Because of the high price of the connection, property developers in Macdonald were not enthusiastic with this requirement. For the two operations of Paris Rive Gauche, there is no imposed energy resource for heating. We must note that a district heating network is present in the three project territories studied, but in Paris Nord-Est and Clichy-Batignolles networks are currently under construction. In Paris Rive Gauche, a study comparing the different energy resources available on site is required. For Tolbiac Chevaleret, the resources whose technical and economic feasibility must be compared are listed. Masséna Bruneseau requirements detail comparison criteria. In addition, installation of solar panels is recommended, while the share of solar energy for domestic water heating must not exceed $50 \%$ of annual demand in Tolbiac Chevaleret.

All these objectives are presented in Table 1. After this first comparison, we cannot draw any conclusion about a temporal evolution of the ways of prescribing energy quality of buildings within these six urban operations. Apart from the consumption targets' evolution due to the adoption of the Parisian Climate Protection Plan, there is no characteristic development in renewable energy production or certification requirements. There seems to be no common strategy between operations within a same urban development project. The only aspect shared between operations of a same project is the 
connection to the district heating system prescription in Paris Nord-Est and Clichy-Batignolles.

Table 1. Comparison of the requirements in terms of energy consumption targets, building certification and renewable energy production

\begin{tabular}{|c|c|c|c|c|c|c|}
\hline & $\begin{array}{c}\text { Masséna } \\
\text { Bruneseau } \\
\text { plots B1A-1 } \\
\text { and } 2\end{array}$ & $\begin{array}{c}\text { Tolbiac } \\
\text { Chevaleret } \\
\text { block T7 }\end{array}$ & $\begin{array}{c}\text { ZAC } \\
\text { Claude } \\
\text { Bernard }\end{array}$ & Macdonald & $\begin{array}{c}\text { ZAC } \\
\text { Clichy- } \\
\text { Batignolles }\end{array}$ & Saussure \\
\hline $\begin{array}{c}\text { Primary } \\
\text { energy } \\
\text { consumption } \\
\text { targets }\end{array}$ & $\begin{array}{c}50 \\
\mathrm{kWh} / \mathrm{m}^{2} \text { year }\end{array}$ & $\begin{array}{c}50 \\
\mathrm{kWh} / \mathrm{m}^{2} \text { year }\end{array}$ & $\begin{array}{c}50 \\
\mathrm{kWh} / \mathrm{m}^{2} \text { year }\end{array}$ & $\begin{array}{c}50 \\
\mathrm{kWh} / \mathrm{m}^{2} \text { year }\end{array}$ & $\begin{array}{c}50 \\
\mathrm{kWh} / \mathrm{m}^{2} \text { year } \\
\text { and } \\
\text { a specific } \\
\text { target for } \\
\text { every } \\
\text { consumption } \\
\text { unit } \\
\end{array}$ & $\begin{array}{c}50 \\
\mathrm{kWh} / \mathrm{m}^{2} \text { year }\end{array}$ \\
\hline $\begin{array}{l}\text { Certification } \\
\text { required }\end{array}$ & $\begin{array}{c}\text { H\&E } \\
\text { (CERQUAL) }\end{array}$ & $\begin{array}{c}\text { H\&E } \\
\text { (CERQUAL) }\end{array}$ & $\begin{array}{c}\text { H\&E } \\
(\text { CERQUAL) }\end{array}$ & $\begin{array}{c}\text { H\&E } \\
(\mathrm{CERQUAL})\end{array}$ & $\begin{array}{c}\text { H\&E } \\
(\mathrm{CERQUAL})\end{array}$ & $\begin{array}{c}\text { No } \\
\text { certification } \\
\text { required }\end{array}$ \\
\hline $\begin{array}{l}\text { Renewable } \\
\text { energy } \\
\text { production }\end{array}$ & $\begin{array}{c}\text { No } \\
\text { quantified } \\
\text { target; } \\
\text { study } \\
\text { comparing } \\
\text { the different } \\
\text { energy } \\
\text { resources } \\
\text { available on } \\
\text { site } \\
\text { required; } \\
\text { installation of } \\
\text { solar } \\
\text { panels } \\
\text { recommended }\end{array}$ & $\begin{array}{c}\text { No } \\
\text { quantified } \\
\text { target; } \\
\text { study } \\
\text { comparing the } \\
\text { different } \\
\text { energy } \\
\text { resources } \\
\text { available on } \\
\text { site required; } \\
\text { installation of } \\
\text { solar } \\
\text { panels } \\
\text { recommended }\end{array}$ & $\begin{array}{l}25 \% \text { of the } \\
\text { final energy } \\
\text { demand; } \\
\text { connection } \\
\text { to the heat } \\
\text { network } \\
\text { requested }\end{array}$ & $\begin{array}{l}25 \% \text { of the } \\
\text { final energy } \\
\text { demand; } \\
\text { connection } \\
\text { to the heat } \\
\text { network } \\
\text { requested }\end{array}$ & $\begin{array}{c}96 \\
\text { MWh/year } \\
\text { of solar } \\
\text { electricity } \\
\text { injected } \\
\text { into the } \\
\text { grid; } \\
\text { connection } \\
\text { to the heat } \\
\text { network } \\
\text { requested }\end{array}$ & $\begin{array}{l}\text { No } \\
\text { quantified } \\
\text { target; } \\
\text { connection } \\
\text { to the heat } \\
\text { network } \\
\text { requested }\end{array}$ \\
\hline
\end{tabular}

\section{Different methods of prescription}

Five types of recommended measures. We have identified five types of recommended measures concerning energy quality of buildings: prescribed actions, quantified targets, required standards, objectives without specified methods and specific technical studies to conduct. According to us, these types of prescriptions can be ranked according to their degree of stringency. Prescribing precise actions is the most binding way of prescription, since there is no room left for the building design team. A prescribed action is a precise prescription concerning material, equipment or design choices, such as: "generalize control and programming devices, according to use: timer, motion detectors, photoelectric lighting sensor" [16]. With prescriptions which commit to achieve an objective, either a quantified target or a standard, designers have to find the way to achieve it. In this way, a minimum performance level is ensured, while with "objectives without specified methods" there is no guarantee of achievement. With this kind of prescriptions, only parameters needed to be taken into account in the design process are specified, such as: "design outdoor lighting according to use". Requiring technical studies can ensure that designers will make an informed decision. 
We have counted the number of prescriptions of each type to compare the strategies adopted in the six operations (Figure 3).

Large use of prescribed actions. We observe that some documents are more stringent than others. The large majority $(83 \%)$ of the prescriptions made for Macdonald residential buildings are objectives without any specified methods, whereas at the opposite, there aren't any of them for ZAC Clichy-Batignolles. The Macdonald case appears to be an exception. In fact, prescribed actions are the most used kind of prescription in three cases (Masséna Bruneseau, Tolbiac Chevaleret and Saussure), representing between $32 \%$ and $55 \%$ of the prescriptions. If prescribed actions are less used in ZAC Clichy-Batignolles specifications, it is for the benefit of targets to achieve. Standards are required in private operations only, Macdonald and Saussure. Apart from the total primary energy consumption target, there is no quantified target or standard demanded in the Masséna Bruneseau specifications for plots B1A-1\&2. But, for the whole sector recommendations of Masséna-Bruneseau, there are quantified targets and fewer studies requested.
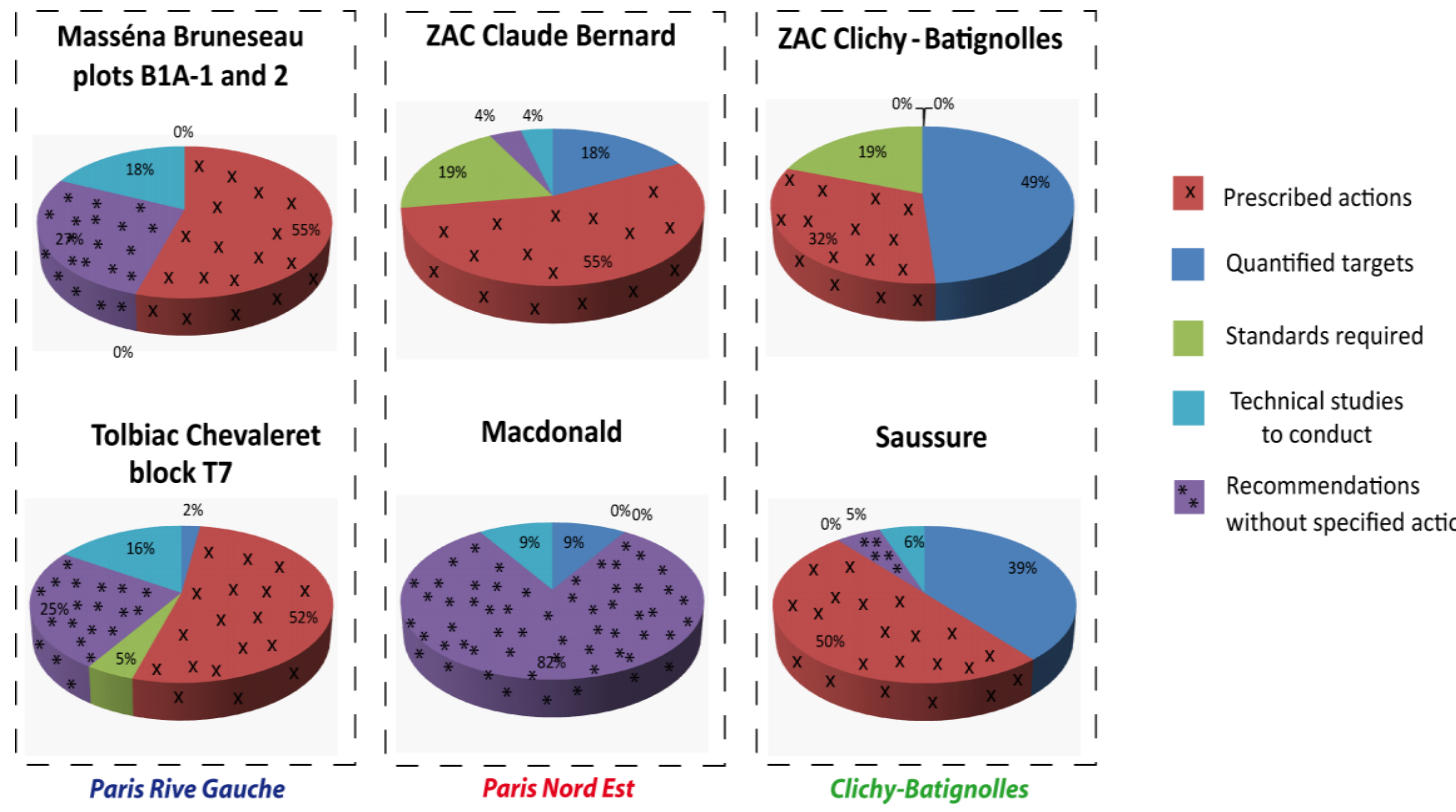

Figure 3. The different types of prescriptions made in the six operations and their distribution

Apart from the large use of prescribed actions, there is no uniformity of prescribing methods. We need to check if this variability also concerns specifications content: what are the parameters on which it is recommended to act on and how is energy quality of building projects monitored?

\section{SPECIFICATIONS CONTENT}

\section{Design choices concerned by prescriptions}

Almost no consensual actions ensuring building performance. We have compared the identified parameters used in environmental specifications to ensure building energy quality. We have grouped the prescriptions under eight categories from architectural options to characteristics of materials and quality of outdoor spaces (Figure 4):

- Architectural criteria concern the form and the orientation of the building; 
- Building shell refers to the thermal characteristics of the walls and roof;

- Comfort and energy needs' category includes all the requirements that focus on visual or thermal comfort;

- Equipment refers to requirements focus on characteristics of ventilation, lighting, boiler, etc.;

- Energy supply criteria focus on types of energy that must be used by the building;

- Outdoor spaces'category contain all the criteria about outdoor spaces quality;

- Materials refers to the environmental characteristics of the materials chosen;

- Energy consumption monitoring refers to all the devices installed to help users to manage their consumption.

Over the 60 parameters mentioned, only one is shared by all of the projects: the installation of solar panels on roofs to produce domestic hot water. Only 10 parameters are mentioned in a majority of operations. This confirms that there is not only one way to ensure building energy performance.

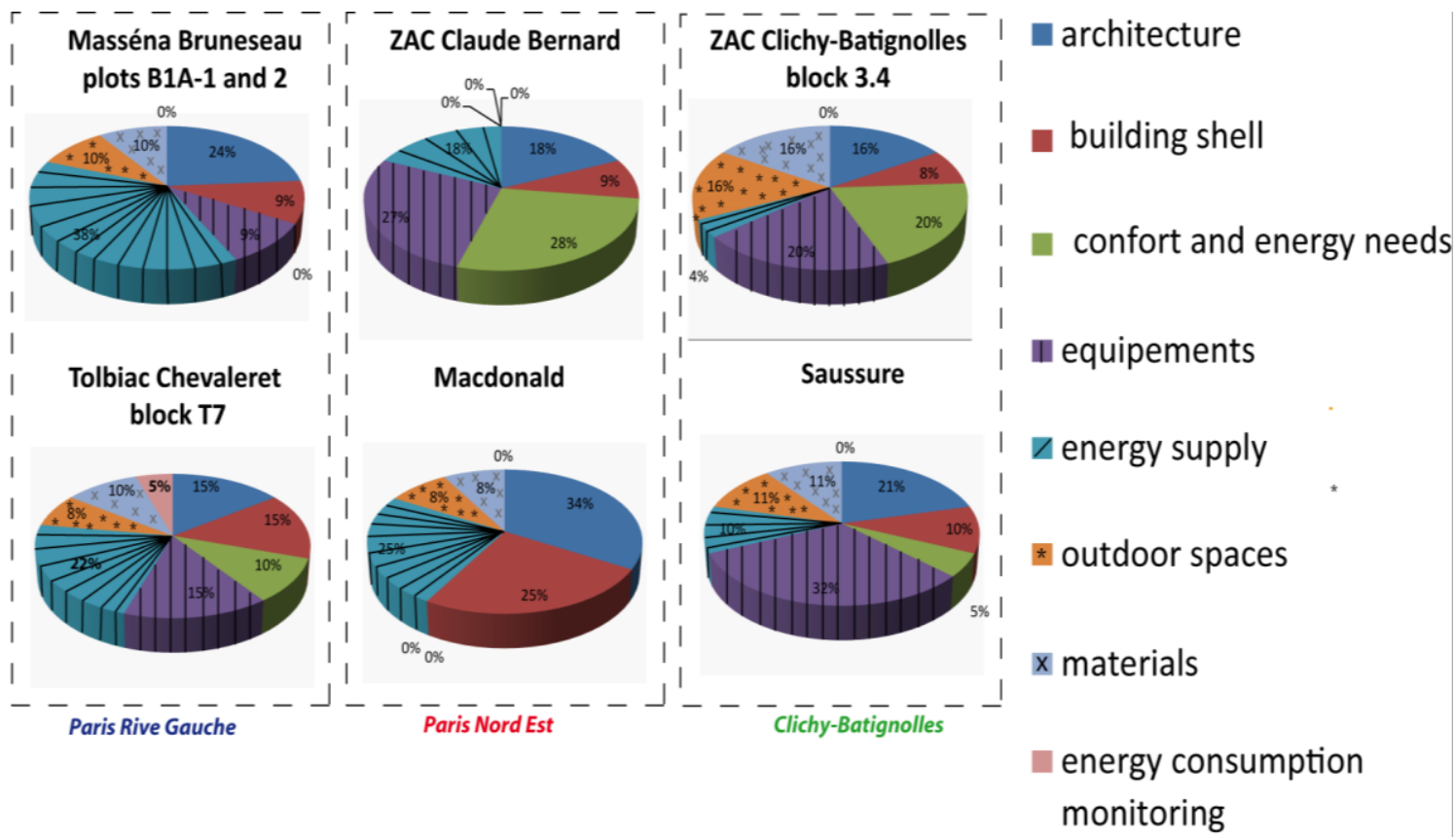

Figure 4. Categories of parameters mentioned in the specifications and their distribution

Everyone has his own concerns. As you can see on Figure 4, distribution of the parameters considered in environmental specifications is very disparate. Every engineering firm seems to have their own concerns. Some insist on a particular part of design, such as energy supply in Masséna Bruneseau or characteristics of equipment in Saussure. On the contrary, in Tolbiac Chevaleret, all the thematics are more or less equally covered. Moreover, Tolbiac Chevaleret is the only one to prescribe energy consumption monitoring equipment during the building's lifetime. Exactly the same thematics are covered in the two subdistrict operations of Clichy-Batignolles. The way of presenting prescriptions in these two documents are similar. In fact, every topic is detailed in three steps: "fundamental requirements", "bioclimatic and architectural requirements" and "detailed technical requirements". Masséna Bruneseau case is interesting, because topics mentionned for whole sector recommandations are really different from the ones for plots B1A-1\&2. For example, a large part of whole sector recommendations are about equipment characteristics, whereas for plots B1A-1\&2, 
emphasis is on energy supply. Concerns about outdoor spaces and material quality appear in the version for plots B1A-1\&2, whereas the ones about comfort and energy needs disappear.

\section{Technical parameters to be considered for each design aspect}

The different recommendations made to ensure building energy performance can be grouped according to eight kinds of design choices. The parameters considered for each choice are detailed in the following paragraphs.

1. Architecture. Concerning architecture, parameters largely used are building orientation, access to natural light, natural ventilation and solar protections. Taking exposure to winter winds into account is recommended in Masséna Bruneseau only. The wind rose of the site is given for winter and summer, in order to identify the direction of the main winds. If building orientation must be considered in most of the projects, winter sunshine is specified only for Masséna Bruneseau and ZAC Clichy-Batignolles. Impact of future buildings on their local environment, in particular shadows created on other buildings is only mentioned in specifications for Tolbiac Chevaleret T7 block.

2. Building shell. Prescriptions for building shells are complete for Tolbiac Chevaleret. Energy losses through walls, air tightness, thermal bridges, thermal inertia, light transmission factor and thermal performance of glazing must be optimized. High thermal performance of glazing is prescribed in all projects, except ZAC Claude Bernard.

3. Comfort and energy needs. No major parameter appears concerning comfort and energy needs, but three are shared by half of the operations - lighting duration, heating duration and indoor temperature of discomfort (this indicator is used to ensure comfort of users during summer). Minimal indoor temperature is demanded for ZAC Claude Bernard and ZAC Clichy-Batignolles only. Duration of mechanical ventilation is used only for the latter.

4. Energy supply. Solar panels for domestic hot water production are recommended in every case, while installation of photovoltaic panels on roofs is mentioned for Tolbiac Chevaleret, Macdonald, Saussure and Masséna Bruneseau and compulsory for ZAC Clichy-Batignolles as written above. Studies on the feasibility of renewable energy production are required for Tolbiac Chevaleret and Masséna Bruneseau, where there is no connection to the district heating system demanded. The energies to be analyzed are heat pumps using aquifer spans or vertical probes, or exchanging energy between spaces with different functions housing and commercial or housing and offices, and connection to the district heating system. If the energy exchange solution is not mentioned for Masséna Bruneseau plots B1A-1\&2, it must be studied for plot B3A of the same sector. Plot B3A is a tall mixed function building, so most interesting for this technology. Grey-water heat recovery must also be studied in Masséna Bruneseau, as well as wind energy production even if it is in principle not suitable. In Tolbiac Chevaleret, wind energy is clearly rejected.

5 - 6. Equipment and materials. Prescriptions about equipment are relatively detailed for Tolbiac Chevaleret, ZAC Clichy-Batignolles and Saussure. They concern the type of controlled ventilation, its power and its airflow. Air conditioning systems must also be avoided and be replaced by passive solutions. Collective heating is recommended in three operations. Paying attention to environmental impacts of materials is largely 
recommended, but durability and ease of maintenance of equipment are considered in Tolbiac Chevaleret, ZAC Clichy-Batignolles and Saussure only. Embodied energy of materials must be calculated for ZAC Clichy-Batignolles, with a given formula. The Masséna Bruneseau specifications demand that the carbon impact of materials be limited with low embodied energy. Local materials must be favoured in Tolbiac Chevaleret and ZAC Clichy-Batignolles.

7. Outdoor spaces. Finally, revegetation of outdoor spaces is identified solely in Claude Bernard project to ensure climatic comfort during summer. These spaces must be protected from the wind in Tobliac Chevaleret and Masséna Bruneseau.

8. Energy consumption monitoring. As written above, energy consumption monitoring equipements during the building's lifetime are required for Tolbiac Chevaleret only.

\section{A common need to monitor energy quality at the different project phases}

The ways of monitoring energy quality of future buildings during the project process are quite similar in all the operations studied. Designers taking part in the architectural competition of Masséna Bruneseau plots B1A-1\&2 must describe the building shell quality, the energy concept, how they will achieve Climate Protection Plan objective, the environmental quality of their project and the results of solar studies. In Tolbiac Chevaleret, solutions chosen to ensure building energy performance must be described for the competition, and justified during preliminary design. Energy supply studies must be provided for building permit request. These data must be updated in the next steps. For ZAC Clichy Batignolles, a table must be filled out at different steps (architectural competition, front-end engineering design, submission of the consultation file and building delivery). There is also a table of indicators in Macdonald specifications, but this one needs to be filled out with the first draft, when the building permit is requested and at delivery. In Saussure, bioclimatic and architectural requirements must be specified for preliminary design and "detailed technical requirements", when the front-end engineering is designed or the consultation file is submitted. Documents demanded at every phase of the project are listed in ZAC Claude Bernard specifications. For the architectural competition, a precise description of the project is needed. For example, equipment used, energy consumption target, wall composition, U-values, selection criteria of materials, and the share of energy demand covered by renewable energy must be specified. Energy consumption of the building and material choices have to be detailed for the consultation file submission. The peculiarity of ZAC Claude Bernard is that an evaluation is required two years after the delivery concerning energy consumption, ageing and maintenance of materials.

\section{CONCLUSION}

Finally, there are four kinds of procedures to guarantee energy quality of buildings in urban development project in Paris: energy consumption targets of the Parisian Protection Plan and of the national Thermal Regulation, specific environmental requirements and environmental certifications. Urban developers need apparently to prescribe the way to reach the energy consumption target of the national Thermal Regulation or Parisian Protection Plan. If environmental requirements drafting seems to be a widespread practice in Parisian urban development projects, there are no common methods to write them. These documents seem to be used in addition to normative 
procedures in order to take features of each operation into account, and so fill out the lack of the national and local regulations.

The way of prescribing energy performance varies from one project to another. We showed that this variability also affects sector projects of the same urban development project. Therefore, we can conclude that energy quality concerns do not arise at the large urban development scale. However, prescriptions about energy supply and renewable energy source choices are similar for sectors of a same project. When a district heating system is under construction in the area of the urban development project, connection of the future building to the network is required.

Most of the environmental specifications we studied are written by engineering firms working as Assistant to the urban Contracting Authority (ACA). As such, they are not involved in the preliminary urban drawing with the designer team. If most of them prefer prescribing precise actions, some do not. Architecture, building shell and energy supply are the only concerns shared by all the environmental spcecifications. However, differences in priorities from one firm to another lead to a high variability of parameters identified to ensure high building energy performance. Variability of the principles adopted in green specifications of construction organisations was already noticed by Lam et al. [10].

We can assume that the differences observed in the way of prescribing building energy performances result from the variety of context and stakeholders, and overall from the different engineering firm experiences. We need therefore to continue the interviews with environmental engineering firms to identify the variation of their methods from project to project. To confirm these results, analysis of green specifications practices from other cities or countries are needed. For the moment, too few studies have been done may be due to lack of data availability.

As there is no measurement of the effective energy consumption of buildings after their delivery, we cannot conclude on the effectiveness of these environmental requirements. Prescribing practices of the energy performance of buildings could not be improved without data on actual consumption of buildings.

\section{REFERENCES}

1. IEA, World Energy Outlook, Paris: IEA Publications, 2008.

2. Steemers, K., Energy and the City: Density, Buildings and Transport, Energy and Buildings, Vol. 35, No. 1, pp 3-14, 2003, http://dx.doi.org/10.1016/S0378-7788(02)00075-0

3. Audessat, N., David, C. and David, F., Le bilan carbone de Paris: Bilan des émissions de gaz à effet de serre, Paris, 2007.

4. de Paris, M., Paris Climate Protection Plan, Paris, 2007.

5. Alyami, S. H. and Rezgui, Y., Sustainable Building assessment Tool Development Approach, Sustainable Cities and Society, Vol. 5, pp 52-62, 2012, http://dx.doi.org/10.1016/j.scs.2012.05.004

6. Lee, W. L. and Burnett, J., Benchmarking Energy use Assessment of HK-BEAM, BREEAM and LEED, Building and Environment, Vol. 43, No. 11, pp 1882-1891, 2008, http://dx.doi.org/10.1016/j.buildenv.2007.11.007

7. Roderick, Y., Mcewan, D., Wheatley, C. and Alonso, C., Comparison of Energy Performance Assessment between LEED, BREEAM and GREEN STAR, Eleventh International IBPSA Conference Glasgow, Glasgow, July 27-30, 2009, pp 1167-1176.

8. Zeinal Hamedani, A. and Huber, F., A Comparative Study of DGNB, LEED and BREEAM Certificate Systems in Urban Sustainability, WIT Transactions on Ecology 


and the Environment, Vol. 155, pp 121-132, 2011,
http://dx.doi.org/10.2495/SC120111

9. Lee, W. L., A Comprehensive Review of Metrics of Building Environmental assessment Schemes, Energy and Buildings, Vol. 62, No. 0, pp 403-413, 2013, http://dx.doi.org/10.1016/j.enbuild.2013.03.014

10. Lam, P. T. I., Chan, E. H. W., Chau, C. K., Poon, C. S. and Chun, K. P., Environmental Management System vs Green Specifications: How do they Complement Each Other in the Construction Industry?, Journal of Environmental Management, Vol. 92, No. 3, pp 788-95, 2011, http://dx.doi.org/10.1016/j.jenvman.2010.10.030

11. SEMAPA, Ateliers Lion Architectes Urbanistes, and TRANSSOLAR, Cahier des charges et recommandations environnementales secteur Masséna Bruneseau, Paris, 2010.

12. Cap Terre and SEMAVIP, ZAC 'Claude Bernard - Quai de la Charente - Canal Saint-Denis' Paris Nord Est/19ème. Cahier des Prescriptions Environnementales Logements, Paris, 2006.

13. Agence Franck Boutté Consultants and ParisNordEst, Reconversion des Entrepôts Macdonald - Logements, Paris, 2010.

14. COTEBA and SNEF, Lotissemnet Saussure Cahier des Prescriptions Environnementales et de Développement Durable Logements, Paris, 2009.

15. SEMAVIP, TRIBU, IZUBA, ENERTECH, HESPUL, AMOES, SEPIA, Atelier François Grether, Jacqueline Osty and OGI, ZAC Clichy-Batignolles Cahier des Prescriptions Environnementales et de Développement Durable (logements, commerces, groupe scolaire, Gymnase) Lot 3.4, Paris, 2010.

16. Iosis Conseil and SEMAPA, Secteur Tolbiac Chevaleret, Cahier des prescriptions environnementales Ilot T7, Paris, 2009.

17. SEMAPA, Ateliers Lion Architectes Urbanistes, and TRANSSOLAR, Fiche environnementale des lots B1A-1 et 2. Secteur Bruneseau, Paris, 2012. 